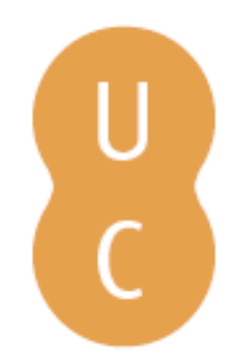

\title{
nombalina
}

\section{Reconstructing the spread of landscape-scale fires in semi-arid southwestern Australia}

\author{
Autor(es): $\quad$ McCaw, Lachlan; Reynen, Vicky; Zdunic, Katherine; Peace, Mika \\ Publicado por: Imprensa da Universidade de Coimbra \\ URL \\ persistente: URI:http://hdl.handle.net/10316.2/34344 \\ DOI: $\quad$ DOI:http://dx.doi.org/10.14195/978-989-26-0884-6_98 \\ Accessed : $\quad$ 26-Apr-2023 14:28:55
}

A navegação consulta e descarregamento dos títulos inseridos nas Bibliotecas Digitais UC Digitalis, UC Pombalina e UC Impactum, pressupõem a aceitação plena e sem reservas dos Termos e Condições de Uso destas Bibliotecas Digitais, disponíveis em https://digitalis.uc.pt/pt-pt/termos.

Conforme exposto nos referidos Termos e Condições de Uso, o descarregamento de títulos de acesso restrito requer uma licença válida de autorização devendo o utilizador aceder ao(s) documento(s) a partir de um endereço de IP da instituição detentora da supramencionada licença.

Ao utilizador é apenas permitido o descarregamento para uso pessoal, pelo que o emprego do(s) título(s) descarregado(s) para outro fim, designadamente comercial, carece de autorização do respetivo autor ou editor da obra.

Na medida em que todas as obras da UC Digitalis se encontram protegidas pelo Código do Direito de Autor e Direitos Conexos e demais legislação aplicável, toda a cópia, parcial ou total, deste documento, nos casos em que é legalmente admitida, deverá conter ou fazer-se acompanhar por este aviso.

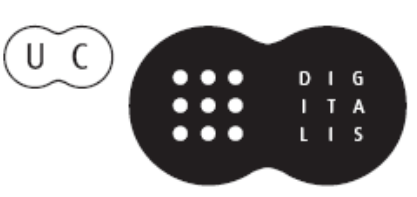




\section{ADVANCES IN}

Forest Fire

\section{RESEARCH}

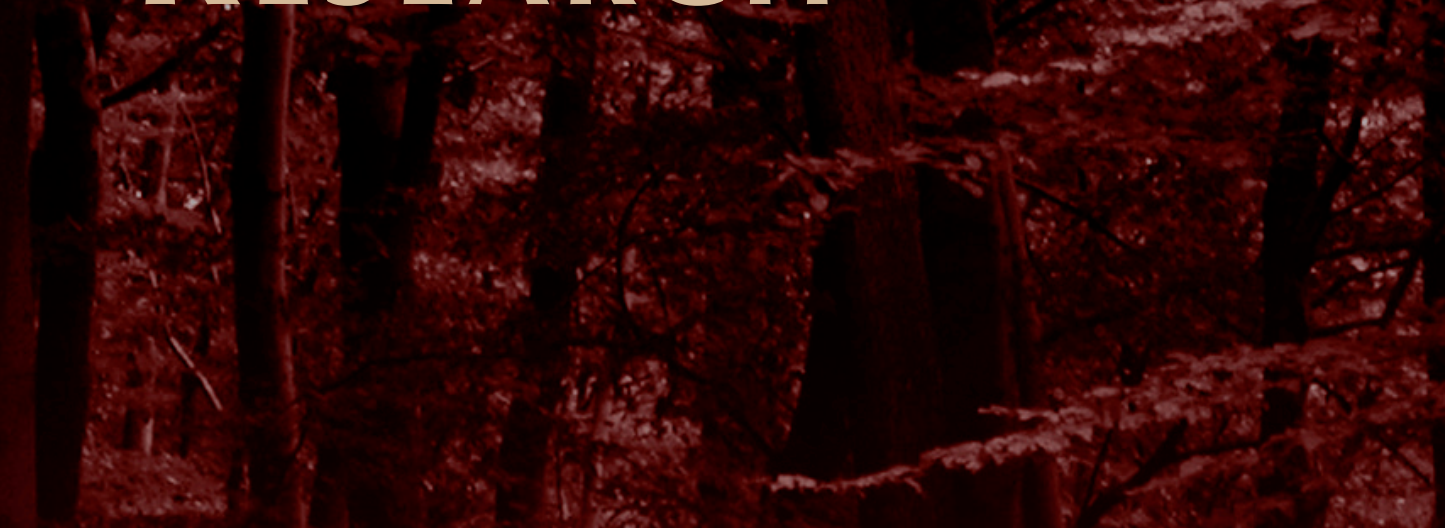

\section{DOMINGOS XAVIER VIEGAS}

\section{EDITOR}




\title{
Reconstructing the spread of landscape-scale fires in semi-arid southwestern Australia
}

\author{
Lachlan McCaw $^{\mathrm{a}}$, Vicky Reynen ${ }^{\mathrm{b}}$, Katherine Zdunic ${ }^{\mathrm{b}}$ and Mika Peace \\ ${ }^{a}$ Department of Parks and Wildlife, Manjimup Western Australia, lachie.mccaw@dpaw.wa.gov.au \\ ${ }^{b}$ Department of Parks and Wildlife, Kensington Western Australia, vicky.reynen@dpaw.wa.gov.au \\ ${ }^{b}$ Department of Parks and Wildlife, Kensington Western Australia, \\ katherine.zdunic@dpaw.wa.gov.au \\ ${ }^{c}$ Bureau of Meteorology, Adelaide South Australia, m.peace@bom.gov.au
}

\begin{abstract}
Landscape-scale fires are a regular feature of semi-arid south-western Australia where the dominant vegetation types are shrubland and eucalypt woodland. Fuel discontinuity limits the spread of fire in some eucalypt woodlands under moderate weather conditions, but fires can spread extensively in woodland under severe fire weather conditions. This paper reconstructs the spread of five large fires ignited by lightning that each burnt more than 90000 ha. Fires remained active for up to 70 days after ignition until they encountered areas of sparse fuel associated with salt lakes and previous burn scars, or were extinguished by rain. Fire perimeters were mapped using daily NOAA AVHRR and MODIS satellite imagery and used to determine periodic growth in fire area. Weather conditions associated with each fire were examined using observations from a limited number of sites. Fire growth was episodic and strongly associated with periods of high temperature, extreme dryness and strong winds. An event of extraordinary fire growth was identified during the 1994 Forrestania fire which increased in area by more than 350000 ha during a 24 hour period. The influence of weather on fire spread is being examined using re-analysis data from the European Centre for Medium-Range Weather Forecasting (ECMWF) Interim Re-analysis project ERA-1 which provides spatial and temporal data coverage not otherwise available due to the sparse observation network. South-western Australia provides a unique opportunity to examine factors influencing the duration, scale and growth characteristics of fires burning in semi-arid landscapes unimpeded by fire suppression. High intensity fires can cause widespread mortality of mature woodland trees with recovery to a mature structure taking several centuries, and the role of fire in development and persistence of eucalypt woodlands is currently a topic of scientific interest. This study forms part of a broader examination of the extent of active fire management, including prescribed burning and fire suppression, appropriate in these landscapes.
\end{abstract}

Keywords: large fires, semi-arid landscapes, lightning ignition, Mediterranean woodlands, satellite imagery

\section{Introduction}

Landscape-scale fires are a regular feature of remote semi-arid areas in south-western Australia where the dominant vegetation types are shrubland and eucalypt woodland. This region of Western Australia is recognised as being of global significance for biodiversity conservation and supports the largest remaining area of intact Mediterranean climate woodland on Earth, known as the Great Western Woodlands (Watson et al. 2008, DEC 2010). The semi-arid landscapes of south-western Australia provide a valuable opportunity to understand factors influencing the duration, scale and growth characteristics of fires burning unimpeded by suppression activities. Weather conditions conducive to the ignition and spread of fire occur from October to April in most years, with regular occurrence of severe fire danger resulting from high temperatures, low relative humidity and strong winds associated with the development of pre-frontal troughs during the summer months (McCaw and Hanstrum 2003). Lightning is a common source of ignition during late spring and summer, and fires may be left to burn without intervention for periods of weeks and sometimes months in remote areas where the human population is small and there are few assets threatened by fire. Patterns of fire spread in the landscape 
are strongly mediated by vegetation type and fuel structure, time since fire, and by the location of natural barriers to fire spread including rocky outcrops and extensive salt lakes (O'Donnell et al. 2011a). The occurrence of very large fires (eg. >100 000 ha) has been linked to climatic patterns that facilitate more extensive spread of fire in eucalypt woodland communities (O'Donnell et al. 2011b, O'Donnell et al. in press). Large fires appear to be driven by inter-annual variation from extremely wet periods to drought periods that promote increased fuel mass and continuity of ephemeral grasses and small shrubs.

Improved understanding of factors controlling the occurrence and scale of fires in semi-arid woodlands and shrublands would benefit land management programs that seek to conserve biodiversity and cultural heritage values (DEC 2010, Prober et al. 2013) and to maintain biomass carbon stocks in longlived woody vegetation (Berry et al. 2009). High intensity fires can cause widespread mortality of mature woodland trees, with recovery to a mature structure taking up to several centuries (Gosper et al. 2013a, b). There is also a need to predict the spread of fires that have potential to impact on communities and settlements, infrastructure such as powerlines and pipelines, and on regional transport corridors vital for communication and economic activity.

This paper reconstructs the spread of five large fires ignited by lightning that developed with little or no effect of fire suppression activity. Our study seeks to better understand the dynamics of large fires by documenting patterns of fire spread and examining weather conditions associated with periods of rapid fire growth. We also identify and discuss topics that will be investigated further as the study develops.

\section{Methods}

\section{Study area}

The five fires examined in this study occurred in or close to the Great Western Woodlands which are bounded on the western and southern sides by the interface with cleared agricultural land, and on the northern and eastern sides by the limits of eucalypt woodland associations and the transition to rangelands held under pastoral lease and subject to extensive grazing by cattle and sheep (Figure 1). Outside of the major regional centre of Kalgoorlie and the towns of Southern Cross and Norseman, the area is sparsely populated by residents of remote pastoral stations, mines and communities of traditional owners. Only a small proportion of the area has been subject to grazing by introduced cattle or sheep, and the vegetation generally retains its natural species composition and structure.

Mean annual rainfall declines across the Great Western Woodlands from $400 \mathrm{~mm}$ in the south-west corner to $250 \mathrm{~mm}$ at the northern limit (Fig.1). Land surfaces are of great antiquity and derived from Archean granite and gneiss of the Yilgarn craton intersected by formations of greenstone and banded ironstone (Beard 1998). The surface of the Yilgarn plateau is gently undulating at elevations between 200 and $500 \mathrm{~m}$ above sea level, with occasional higher points on rocky ranges and granite outcrops. Drainage is occluded with extensive salt lakes indicating the alignment of ancient paleo-drainage systems. Salt lakes are typically bare of vegetation and larger lakes ( $>1 \mathrm{~km}$ wide) are a major barrier to fire spread other than by airborne firebrands. 


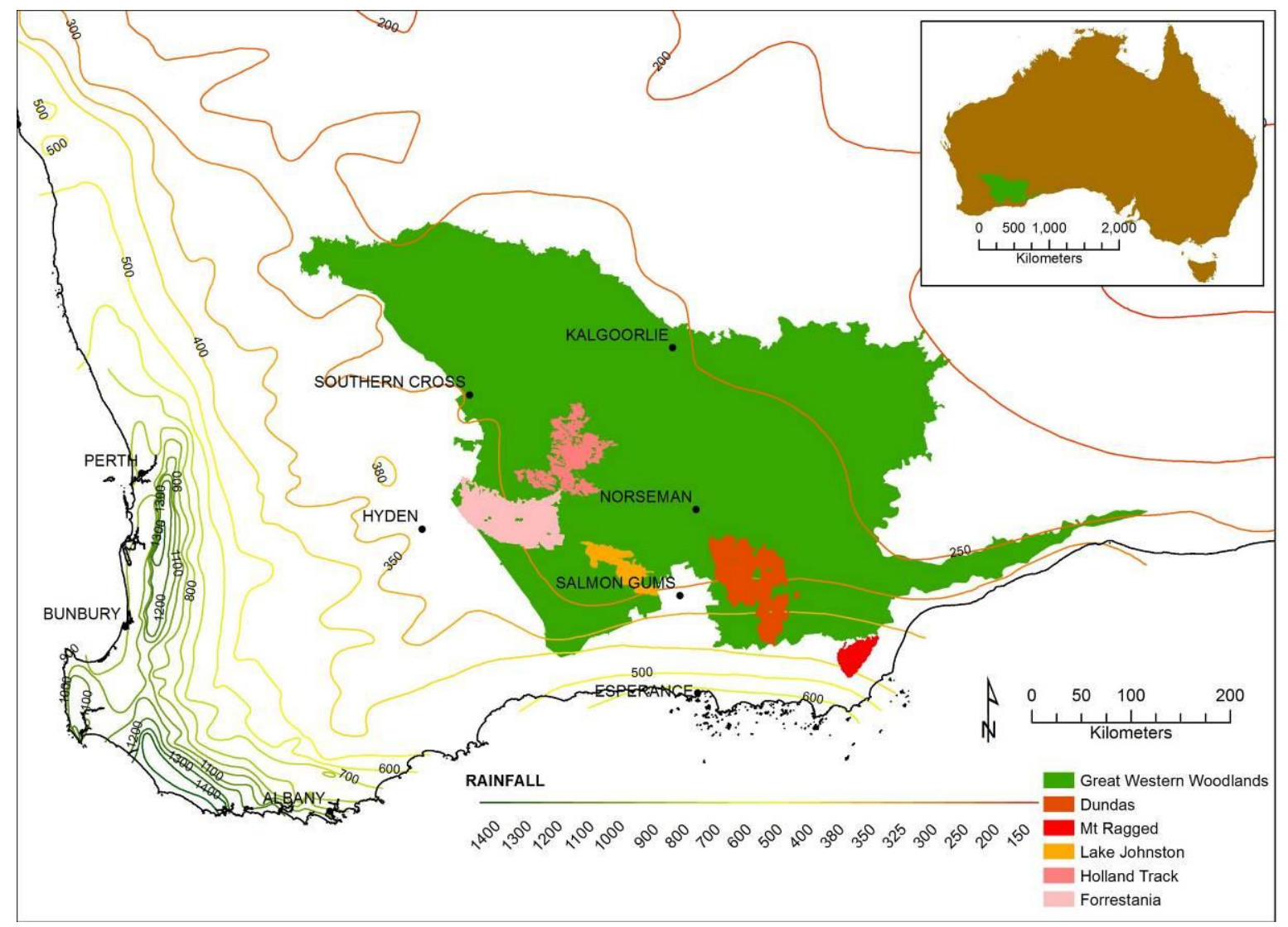

Figure 1. Location of the Great Western Woodlands in south-western Australia

\subsection{Re-constructing fire growth from satellite imagery}

The date and location of ignition, duration of fire activity and final area burnt for the five fires examined in the study are presented in Table 1. Fire perimeters were mapped from sequential satellite imagery dating to a minimum of every second day during the period of fire activity, subject to image availability and cloud coverage. Images were analysed daily during periods when fires were active and fire perimeters changed significantly from one image to the next. Imagery from the AVHRR sensor on the NOAA-11 and NOAA-12 satellites was used to map the perimeters of the Lake Johnson, Dundas, Mt Ragged and Forrestania fires. The NOAA-11 satellite was operational from 1998 to 2004 and the NOAA-12 satellite from 1991 to 2007. The AVHRR sensor acquired data in five bands (red, near infrared and three thermal bands) with an image resolution of $1.09 \mathrm{~km}$. This satellite imagery data is suitable for detecting active fires (Lentile et al. 2006), particularly where fires are large in size and much of the area was burnt at high intensity resulting in significant change in vegetation cover, as was the case for these fires. Fire perimeters were digitised in ERDAS ER Mapper software and subsequently imported into ArcMap for final data manipulation. This analysis utilised archived NOAA imagery held by the CSIRO Earth Observation Centre (http://www.eoc.csiro.au/cats/) and Western Australian Land Information Authority (http://www.rss.dola.wa.gov.au/newsite/noaaq1/NOAAsearch.html).

Progression of the 2004/05 Holland Track fire was derived from MODIS constellation imagery. Imagery from both the Terra satellite (launched 1999) and the Aqua satellite (launched 2002) was used, and contains 36 bands at varying resolutions from 250 to 1000 metres. Natural colour displays using bands red, green and blue were created and used to interpret burnt areas. Digitizing of fire perimeters was undertaken in ArcMap. The archive of MODIS data was accessed from the 
Western Australian Land Information Authority Firewatch service (http://firewatch.landgate.wa.gov.au/landgate_firewatch_public.asp).

Table 1. Details of large fires reconstructed using satellite imagery

\begin{tabular}{lrccc}
\hline Fire & Ignition date & Ignition location & $\begin{array}{c}\text { Duration of fire } \\
\text { activity } \\
\text { (days) }\end{array}$ & Final fire area \\
& (dd/mm/yyyy) & (Lat./long.) & (ha x 10 ${ }^{3}$ ) \\
\hline Lake Johnston & $19 / 12 / 1990$ & $-32.7 / 120.7$ & 36 & 151 \\
Dundas & $20 / 12 / 1990$ & $-32.6 / 122.3$ & 70 & 478 \\
Mt Ragged & $6 / 01 / 1991$ & $-33.3 / 123.5$ & 53 & 93 \\
Forrestania & $21 / 01 / 1994$ & $-32.2 / 119.3$ & 9 & 466 \\
Holland Track & $5 / 12 / 2004$ & $-31.8 / 120.2$ & 37 & 311 \\
\hline
\end{tabular}

\subsection{Weather}

The network of weather observation sites representative of the Great Western Woodlands is sparse and restricted to larger settlements mostly located on the margins of the area including Southern Cross, Hyden, Kalgoorlie and Salmon Gums, with Norseman being more centrally located (Figure 1). Automatic weather stations capable of continuous recording began to be installed at these sites from the mid-1990s but did not exist at the time of the Lake Johnson, Dundas, Mt Ragged and Forrestania fires. Balloon sondes launched daily at Kalgoorlie provide atmospheric observations above the surface level. The ignition points of all fires examined for this study were at least $75 \mathrm{~km}$ from the closest weather observation site, and in some case much further. In selecting weather observations representative of each fire important considerations are how well the observations reflect the location of the fire relative to pre-frontal troughs and cold fronts advancing from the west, and relative to coastal influences that may moderate extremes of temperature and dryness but be influenced by sea breezes from the Southern Ocean.

Re-analysis data from the European Centre for Medium-Range Weather Forecasting (ECMWF) Interim Re-analysis project ERA-1 provides spatial and temporal coverage of weather data not otherwise available due to the sparse observation network in the study area and is being utilised as an additional source of information for fire reconstructions. Re-analysis data are available 3 hourly on a $75 \mathrm{~km}$ grid worldwide and provide basic variables ( $T, \mathrm{~T}_{\mathrm{d}}$, wind speed and direction) from 1979 onwards. Wain and Kepert (2013) used ERA-1 re-analysis data to develop a comprehensive and nationally consistent climatology of fire weather parameters for the whole of Australia including derived indices for fire danger and atmospheric stability that can provide important insights into factors influencing fire dynamics.

\section{Results}

The five fires examined in our study spanned the southern half of the Great Western Woodlands, with the 1991 Mt Ragged fire in the Cape Arid National Park at the southern extremity of the woodland region (Fig 1.). Three of the fires occurred during the summer (Dec-Feb) of 1990/91 resulting in a burnt area of 722000 ha. Individual fires ranged in final size from 93000 ha for the Mt Ragged fire to 478000 ha for the Dundas fire. The Lake Johnston and Dundas fires were ignited by lightning from dry thunderstorms on 19 December 1990, and the Mt Ragged fire was ignited by lightning on 6 January 1991. 

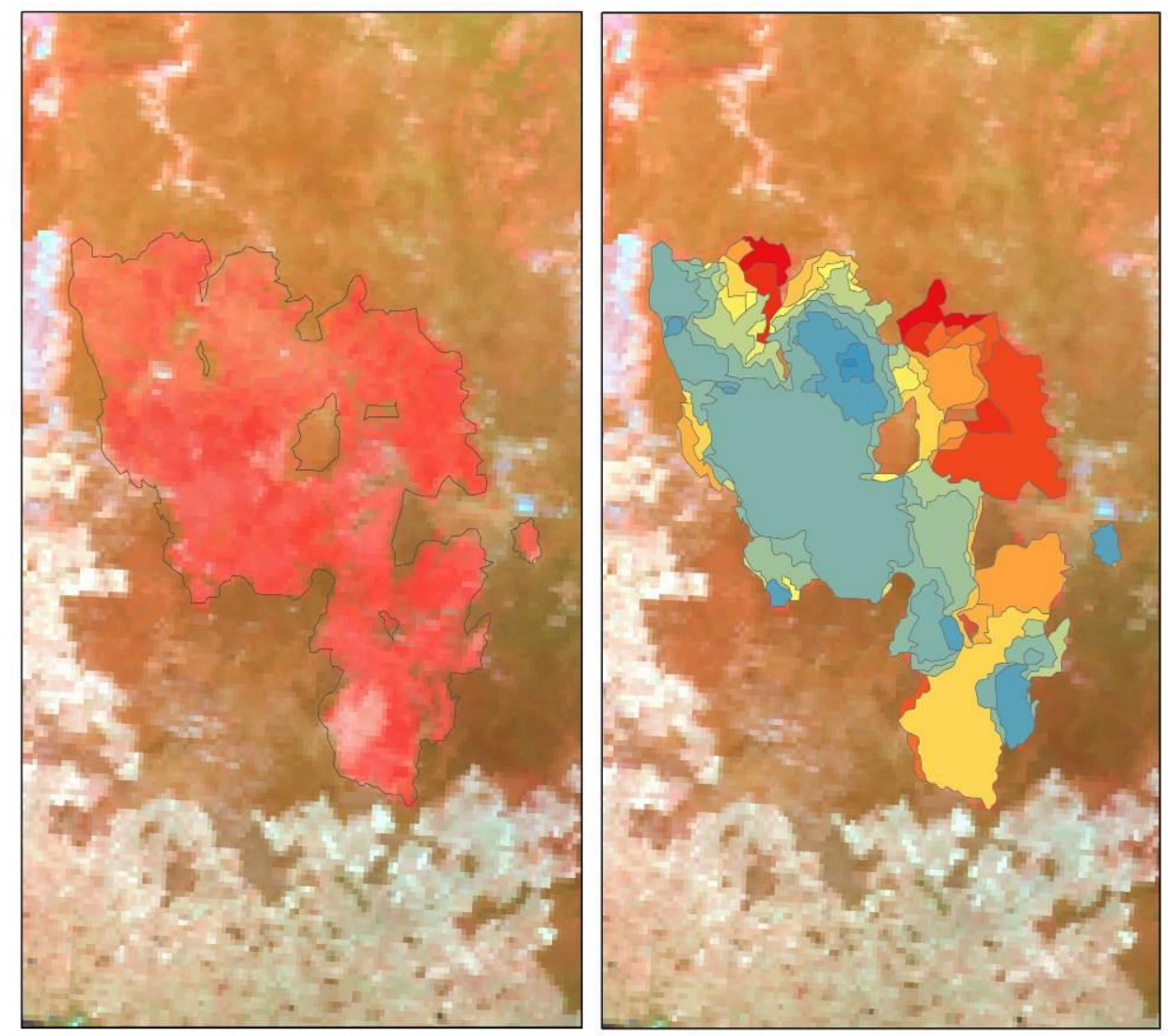

Historical Progression Dundas Nature Reserve Fire (December 1990 - February 1991) Legend

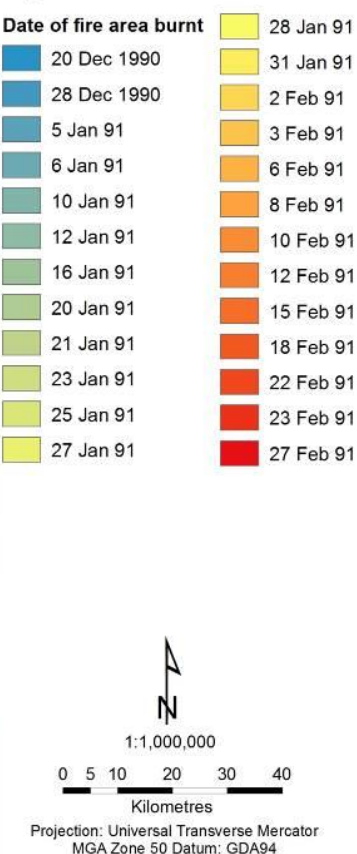

Figure 2. Reconstruction of the Dundas fire from AVHRR satellite imagery between 20 December 1990 and 27 February 1991 showing (a) burnt area and (b) periodic spread
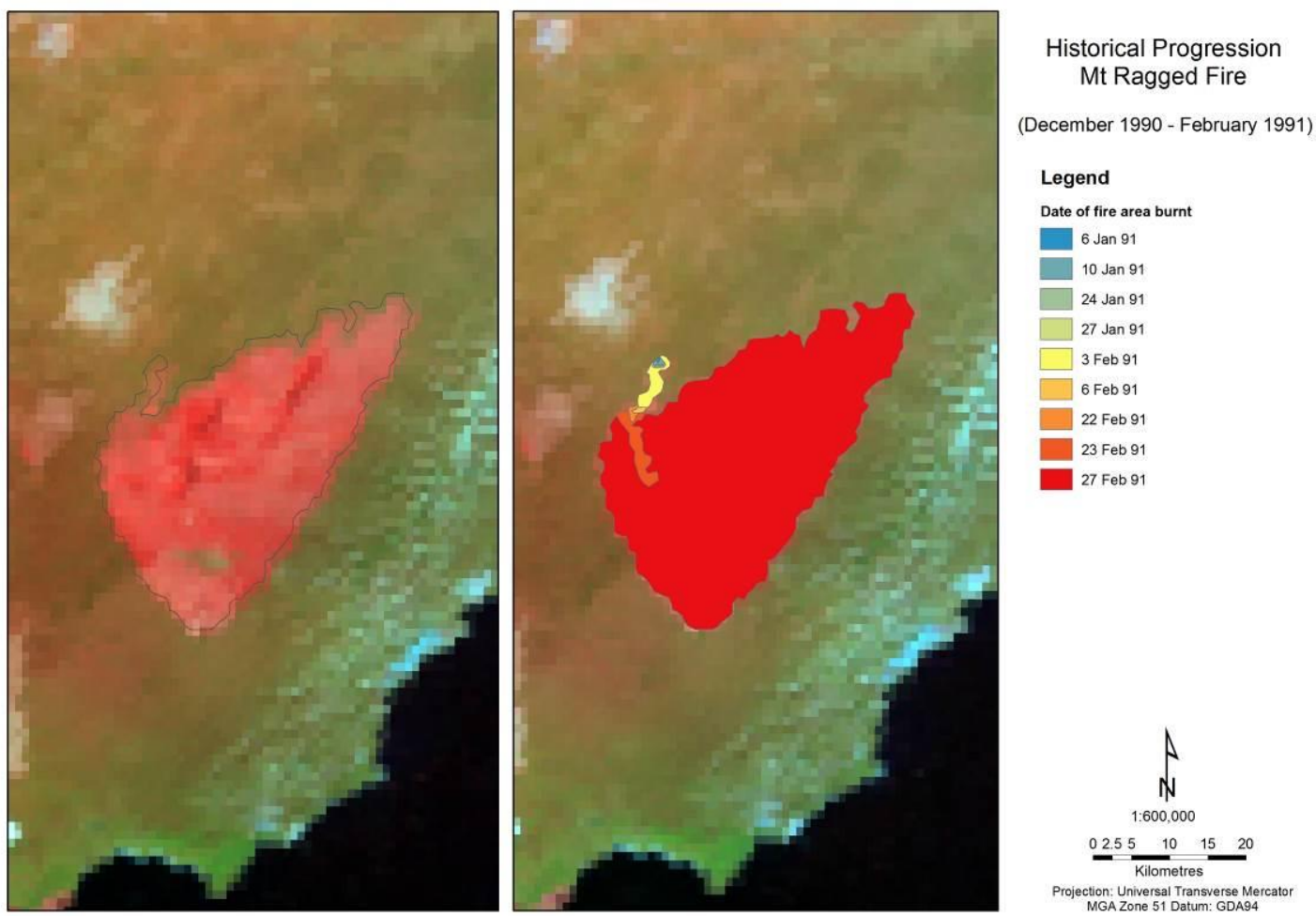

Figure 3. Reconstruction of spread of the Mt Ragged fire from AVHRR satellite imagery between 6 January and 27 February 1991 showing (a) burnt area and (b) periodic spread 

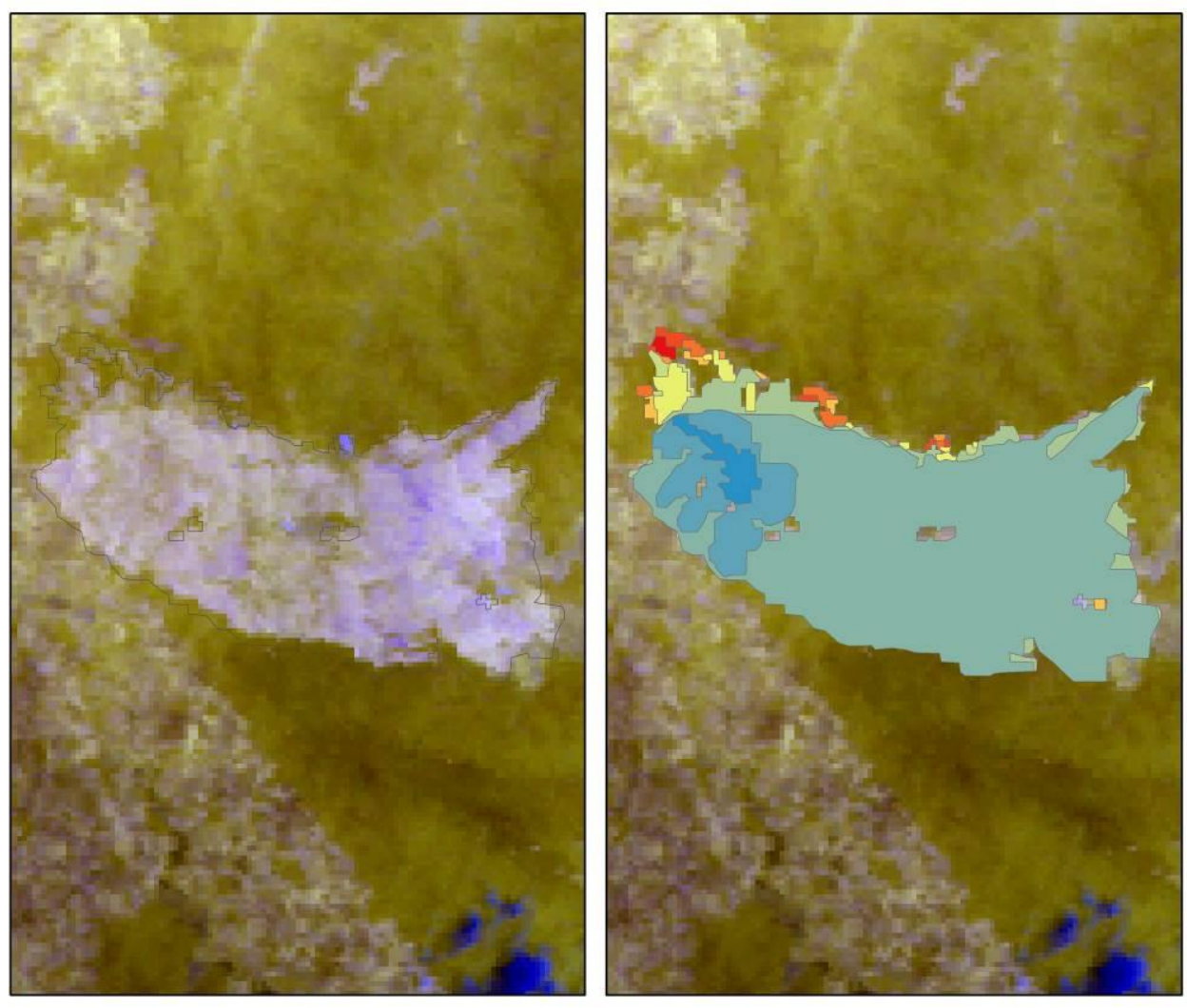
Historical Progression Forrestania Fire
(January 1994)

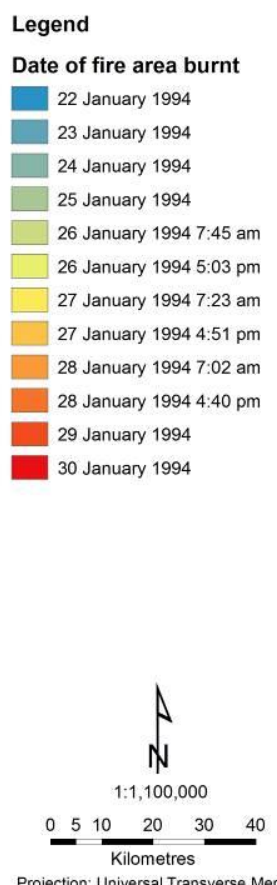

Projection: Universal Transverse Mercator
MGA Zone 50 Datum: GDA94

Figure 4-Reconstruction of spread of the Forrestania fire from AVHRR satellite imagery between 22 and 30 January 1994 showing (a) burnt area and (b) periodic spread

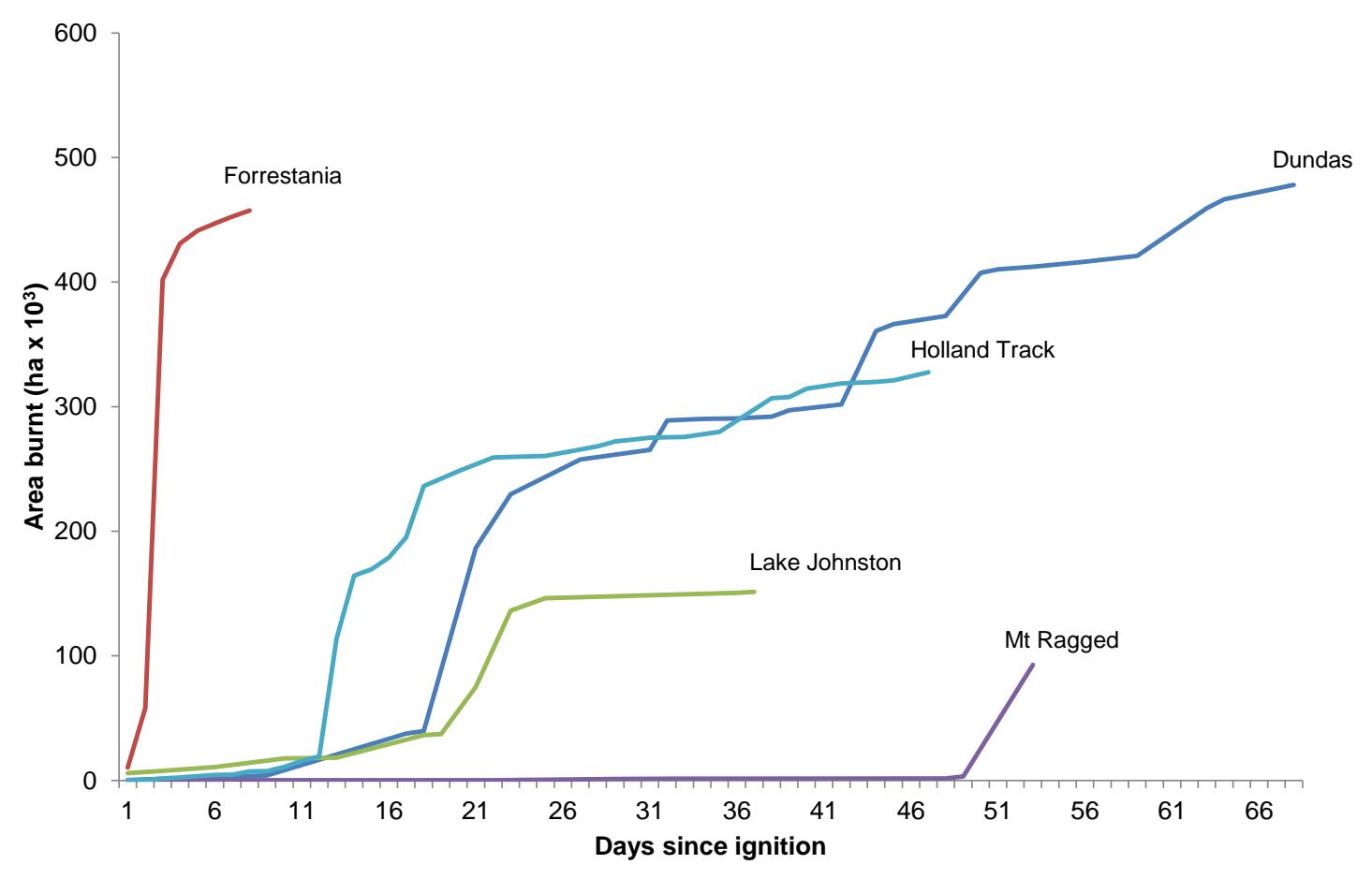

Figure 5. Increase in area burnt following ignition for five large fires 
Fire reconstructions from satellite imagery show that the Mt Ragged and Dundas fires continued to grow through until late February 1991, with corresponding active periods of 53 and 70 days (Figs $2 \&$ 3 ). The 1994 Forrestania fire burnt a very large area (466 000 ha) but was only active between 22 and 30 January, with the major spread event taking place on 24 January (Figure 4). The Holland Track fire was ignited by lightning on 5 December 2004 and remained active for 37 days attaining a final burnt area of 311000 ha.

Fires exhibited different patterns of growth and development (Figure 5). The Lake Johnston and Dundas fires developed at a similar rate to each burn about 40000 ha by 6 January 1991. Both fires then exhibited major spread between 7 and 9 January increasing in size by more than 100000 ha under the influence of dry north-westerly winds and very high temperatures; a maximum temperature of $41^{\circ} \mathrm{C}$ was recorded at Salmon Gums on 8 January. The Lake Johnson fire travelled a distance of approximately $60 \mathrm{~km}$ to Peak Charles where its further spread was constrained by extensive salt lakes. The Dundas fire continued to develop and exhibited further periods of major spread to the south between 28 January and 3 February, and towards the north-east in mid-February. These spread events were also associated with periods of very high temperature $\left(>42^{\circ} \mathrm{C}\right)$ and strong northerly to westerly wind. The Mt Ragged fire exhibited a quite different pattern of development following ignition on 6 January 1991. This fire remained small ( $<200$ ha) throughout January and then grew to 1500 ha in early February, under the same weather pattern that drove the expansion of the Dundas fire. A further period of very high temperature and northerly winds increased the fire size to 3250 ha on 23 February. The major fire spread event took place on 27 February, initially under north-westerly winds through an area burnt previously by a lightning caused fire in 1983, and then under the influence of a strong south-westerly flow that extended the northern flank of fire. Fire growth on 27 February was estimated to be approximately 90000 ha.

The Forrestania fire was ignited by lightning on 22 January 1994 and grew to approximately 10000 ha within the first day of spread. Back-firing from the interface with the cleared agricultural land on 23 January increased the fire area to approximately 58000 ha, with the pattern of the back-firing evident from the remote sensing imagery. An event of extraordinary fire growth took place on 24 January during which the fire increased in size by more than 350000 ha under the influence of northwest and westerly winds. The head of the fire spread up to $80 \mathrm{~km}$ and reached the extensive salt lake at Lake Johnston. Upper air observations from Kalgoorlie show a dry adiabatic atmosphere to more than $5 \mathrm{~km}$ and wind speeds of 46 knots at the $900 \mathrm{hPa}(1000 \mathrm{~m})$ level (Figure 6). Growth of the Forrestania fire on the subsequent five days was relatively small in extent and confined to the northern flank of the fire.

The Holland Track fire was ignited by lightning on 5 December 2004, and underwent an initial period of growth for 10 days similar to that of the 1991 Dundas and Lake Johnston fires (Figure 5). Fire size increased by almost 100000 ha on 17 December, after which time the rate of growth followed a similar trajectory to that of the Dundas fire. Some limited suppression activity including track construction and back-burning was undertaken on the Holland Track fire and this may have influenced its pattern of development during later stages. 


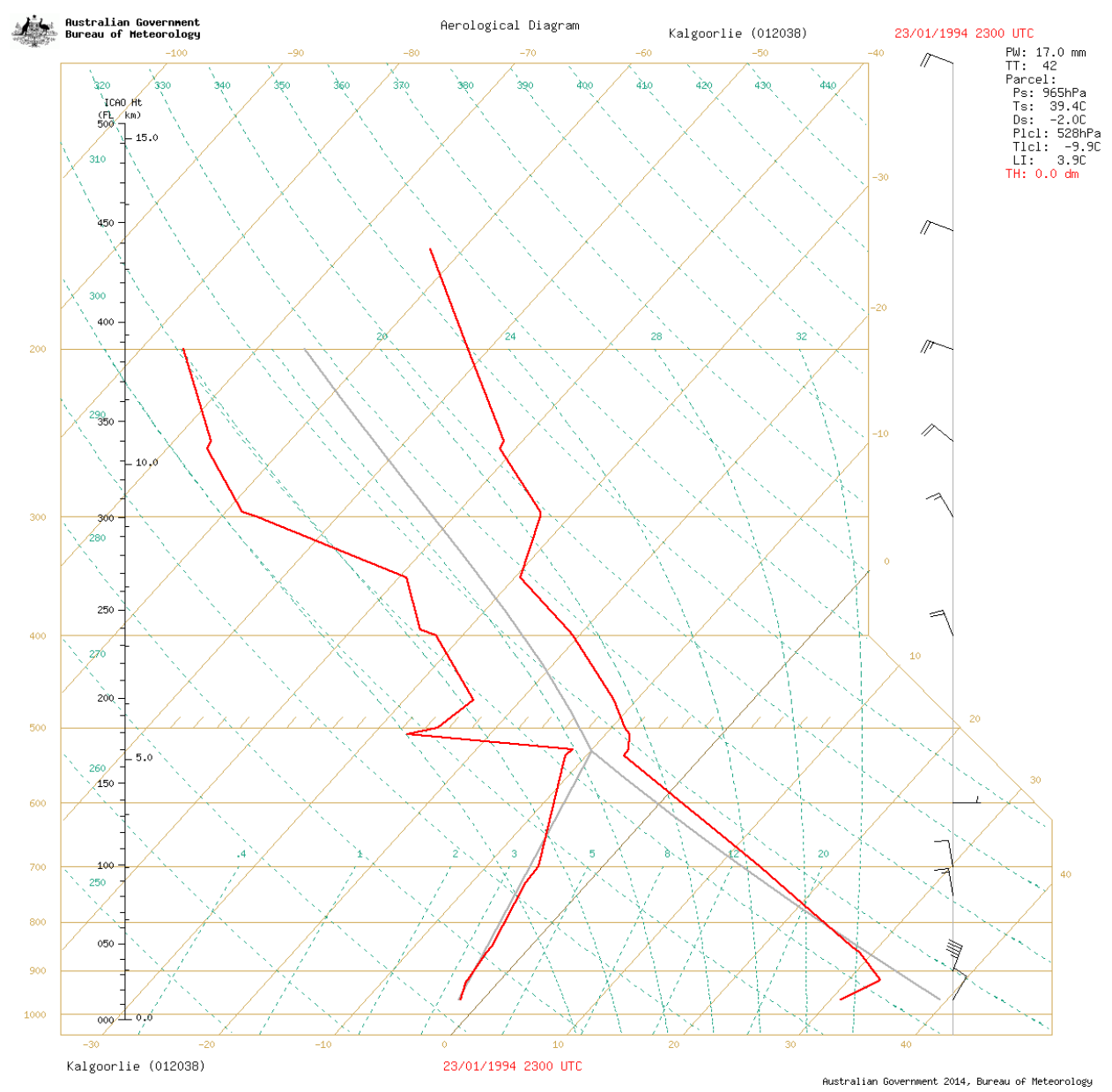

Figure 6. Aerological diagram for Kalgoorlie for 0700 hr Western Standard Time on 24 January 1994

\section{Discussion}

The fires examined in this study are of a size significant at the scale of the Australian continent, and potentially at a global scale. Indeed, the rate of growth of the Forrestania fire may represent one of the largest fire spread events documented for a single fire on one day. The scale of area burnt and rates of fire development are comparable with those documented for Black Saturday 7 February 2009 in southeastern Australia which burned over 450,000 ha and resulted in 173 human fatalities (Cruz et al. 2012). The Kilmore East fire was the most significant of these fires, burning 100,000 ha in less than 12 hours and travelling a distance of around $55 \mathrm{~km}$ under northerly winds before being forced northwards by the passage of a cold front. Understandably, fires burning in remote areas of Australia that do not pose a direct threat to human life or economic activity attract little attention from the community or from fire researchers. However, these large remote fires warrant detailed study because of their environmental impacts on a range of values including biodiversity, atmospheric emissions and carbon storage in long-lived woody vegetation. They also offer insights into dynamic processes of fire spread that are rarely available in more densely populated landscapes.

Further work will be undertaken for this study to examine in greater detail the weather patterns associated with periods of major fire spread and to investigate the association between fire growth and existing fire danger indices used in Australia. We also intend to examine how fire spread is affected by broadscale patterns of vegetation and time since previous fire. 


\section{References}

Beard JS (1998) Position and development of the central watershed of the Western Shield, Western Australia. Journal of the Royal Society of Western Australia 81, 157-164.

Berry S, Keith H, Mackey B, Brookhouse M, Jonson J (2009) Biomass carbon stocks in the Great Western Woodlands. Report for the Wilderness Society (ANU Enterprise Pty Ltd: Canberra)

Cruz MG, Sullivan AL, Gould JS, Sims NC, Bannister AJ, Hollis JJ, Hurley RJ (2012) Anatomy of a catastrophic wildfire: The Black Saturday Kilmore East fire in Victoria, Australia. Forest Ecology and Management 284, 269-285.

DEC (2010) A Biodiversity and Cultural Conservation Strategy for the Great Western Woodlands. (Government of Western Australia, Department of Environment and Conservation: Perth)

Gosper CR, Prober SM, Yates CJ (2013a) Multi-century changes in vegetation structure and fuel availability in fire-sensitive eucalypt woodlands. Forest Ecology and Management 310, 102-109.

Gosper CR, Prober SM, Yates CJ (2013b) Floristic diversity in fire-sensitive eucalypt woodlands shows a 'U'-shaped relationship with time since fire. Journal of Applied Ecology 50, 1187-1196.

Lentile LB, Holden ZA, Smith AMS, Falkowski MJ, Hudak AT, Morgan P, Lewis SA, Gessler PE, Benson NC (2006) Remote sensing techniques to assess active fire characteristics and post-fire effects. International Journal of Wildland Fire 15, 319-345.

McCaw WL, Hanstrum B (2003) Fire environment of the Mediterranean south-west of Western Australia. In 'Fire in ecosystems of south-west Western Australia: impacts and management'. (Eds I Abbott, N Burrows) pp. 87-106. (Backhuys Publishers: Leiden, The Netherlands)

O'Donnell AJ, Boer MM, McCaw WL, Grierson PF (2011a) Vegetation and landscape connectivity control wildfire intervals in unmanaged semi-arid shrublands and woodlands in Australia. Journal of Biogeography 38, 112-124.

O'Donnell AJ, Boer MM, McCaw WL, Grierson PF (2011b) Climatic anomalies drive wildfire occurrence and extent in semi-arid shrublands and woodlands of southwest Australia. Ecosphere 2, Part 127.

O'Donnell AJ, Boer MM, McCaw WL, Grierson PF (in press) Vegetation type and fuel age control wildfire size in semi-arid southwest Australia. Ecosphere accepted 29 May 2014.

Prober SM, Yuen E, O’Connor MH, Schultz L (2013) Ngadju kala: Ngadju fire knowledge and contemporary fire management in the Great Western Woodlands. (CSIRO Ecosystem Sciences: Perth)

Wain A, Kepert JD (2013) A comprehensive, nationally-consistent climatology of fire weather parameters. Report prepared under the National Emergency Management Program, Department of the Attorney General, Canberra.

Watson A, Judd S, Watson J, Lam A, Mackenzie D (2008) The extraordinary nature of the Great Western Woodlands. The Wilderness Society of Western Australia, Perth. 